\title{
Possible Protective Effect of Onion Supplementation on Hepatic Functional and Structural Alterations Induced by Cholestasis
}

\author{
ABD EL-HAMID A. MOHAMED, M.D.; DALIA A. SAAD, M.D.; MARIAN MAGED FRANCIS, M.Sc. and \\ FATMA AHMED MOHAMED, M.D.
}

The Department of Physiology, Faculty of Medicine, Ain Shams University

\begin{abstract}
Background: Cholestasis is the obstruction or the reduction in bile flow that results in intrahepatic accumulation of bile constituents, which progresses to develop liver pathology. Common bile duct ligation (BDL) in rodents is an experimental model of cholestasis that has been carried out in research for many years. BDL model of cholestatic liver injury involves other mechanisms, including oxidative stress, inflammation, and fibrogenesis. Antioxidant, anti-inflammatory or antiapoptotic properties gained much interest for the amelioration of liver dysfunction.
\end{abstract}

Aim of Study: The aim of this study is to assess the possible protective effects of onion supplementation on hepatic structural and functional alterations induced by BDL in rats, which reflect the effects of cholestasis resulting from intrahepatic accumulation of bile.

Material and Methods: Thirty adult female Wistar albino rats were randomly and equally allocated into three groups: (1) Control group, (2) BDL group; subjected to ligation of the common bile duct and (3) Onion-supplemented BDL groups (O-BDL). Both control and BDL groups received distilled water (solvent for onion powder) daily by gavage for 4 weeks. Onion-supplemented BDL group (O-BDL); subjected to ligation of the common bile duct and then received $500 \mathrm{mg} / \mathrm{kg}$ of onion powder dissolved in distilled water, daily by gavage for 4 weeks. At the end of the experimental period, plasma levels of alanine aminotransferase (ALT), aspartate aminotransferase (AST), alkaline phosphatase (ALP), direct bilirubin, total proteins, total antioxidant capacity (TAC), tumor necrosis factor- $\alpha$ (TNF- $\alpha$ ), and hepatic tissue level of malondialdehyde (MDA) and transforming growth factor- $\beta$ (TGF- $\beta$ 1) were measured for all groups. In addition, histopathological examination of liver tissue samples was performed for the three groups.

Results: Plasma levels of ALT, AST, ALP, direct bilirubin, TNF- $\alpha$ and hepatic tissue levels of MDA and TGF- $\beta 1$ were significantly increased and TAC was significantly decreased in the BDL group compared to the control group. In addition, altered architecture was detected in hepatic tissue samples of BDL group. Onion supplementation significantly decreased

Correspondence to: Dr. Dalia A. Saad, E-Mail: drdalia2009@med.asu.edu.eg the plasma levels of ALT, AST, ALP, direct bilirubin, TNF$\alpha$ and hepatic tissue levels of MDA and TGF- $\beta 1$ in the OBDL group when compared to the BDL group. Total proteins level was not significantly different among all the studied groups. In addition in O-BDL group, histopathological examination of liver revealed near normal structure of hepatic tissue.

Conclusion: BDL induces hepatic structural alterations and functional disturbances. Onion supplementation inhibits inflammation and oxidative insults that associate BDL, and subsequently protects against BDL-induced liver injury.

Key Words: Bile duct ligation, Cholestasis - Hepatic structural and functional disturbances - Oxidative stress Onion supplementation.

\section{Introduction}

CHOLESTASIS is the obstruction or the reduction in bile flow that results in intrahepatic accumulation of bile constituents, that progresses to develop liver pathology [1]. Untreated cholestasis was reported to progress to liver fibrosis and cirrhosis, and finally results in liver failure [2]. Bile duct ligation (BDL) has been used as an animal model of chronic liver injury as it is a very good way to mimic the hepatocyte damage and liver fibrosis observed in human liver diseases [3]. Cholestasis was reported to induce hepatic inflammation, which contributes to liver injury during cholestasis, and bile acids were accused of directly activating the production of pro-inflammatory mediators in the liver [4]. Also, oxidative stress was considered to represent a primary cause and/or an aggravating factor in hepatic injury in cholestasis induced by bile duct ligation [5]

Onion has the potential properties in amelioration of health in many aspects as it has antiinflammatory, anti-hyperglycemic and antihyperlipidemic properties $[6,7]$ as well as antimicrobial activity [8] $90 \%$ of onion is water, with high content 
of dietary fiber, sugar, vitamins, anthocyanins mineral and flavonols [9] Flavonols are the onion pigments of which quercetin derivatives are the most important ones [10]. Quercetin flavonoid possesses multiple beneficial effects, including anti-inflammatory and anti-apoptotic properties. Moreover, its anti-oxidative effects are remarkable and demonstrated in many experimental studies against a wide range of hepatic ailments. [11,12] .

However, the detailed comprehensive evaluation of the role of these antioxidant and anti-inflammatory effects of onion powder in cholestasis - induced hepatic injury was poorly evaluated.

\section{Aim of the work:}

To evaluate the effect of bile duct ligation on the hepatic structure and function and to evaluate the possible role of onion in amelioration of hepatic structural and functional alteration caused by bile duct ligation, and the subsequent cholestasis.

\section{Patients and Methods}

\section{Experimental Animals:}

The present study was performed at Physiology Department, Faculty of Medicine, Ain Shams University, from April, 2018 to August, 2018. In this study we used thirty adult female Wistar albino rats initially weighing from 150-250 grams. Rats were purchased from the experimental animal farm of ophthalmology research center (Giza).

Rats were kept in the medical research center of Ain Shams University (MASRI), with free access to water and food ad libitum. Rats were left to be acclimatized to the new environments for 7 days prior to experiments.

All animal experiments performed according to the Ethics Committee of Faculty of Medicine, Ain Shams University and according to the National Institutes of Health guide for the care and use of Laboratory animals (NIH publication No. 8023, revised 1978) [13].

\section{Drugs:}

Dehydrated white onion powder was supplied by City Foods Egypt Company (Giza, Egypt).

\section{Experimental design:}

Thirty adult female albino rats were randomly allocated into three equal groups:

Group 1: Sham-operated control group (C, $\mathrm{n}=10$ rats): Rats in this group were subjected to the same surgical steps as for common bile duct ligation except for ligation of the common bile duct. These rats received a single daily dose of distilled water $(1 \mathrm{ml})$ orally by gavage for 4 weeks.

Group 2: Bile duct ligation group (BDL, $\mathrm{n}=10$ rats): Rats in this group were subjected to the surgical operation of bile duct ligation. These rats, then received a single daily dose of distilled water $(1 \mathrm{ml})$ orally by gavage for 4 weeks.

Group 3: Bile duct ligation-onion powdersupplemented group (O-BDL, $\mathrm{n}=10$ rats): Rats in this group were subjected to the surgical operation of bile duct ligation and then received $500 \mathrm{mg} / \mathrm{Kg}$ body weight of onion powder dissolved in $1 \mathrm{ml}$ distilled water, in a single daily dose, orally by gavage for 4 weeks [14].

After 4 weeks, animals were sacrificed and blood and liver samples were collected for biochemical analysis and histopathological examination.

Bile duct ligation: Surgical steps of bile duct ligation were performed according to the method described by Tag et al., [15] . Cefotaxime (100mg/ $\mathrm{Kg}$ /day) was given by IM injection preoperatively and continued for 3 days after surgery. Rats were anesthetized by IM ketamine injection $(40 \mathrm{mg} / \mathrm{kg}$ ). The abdomen was opened with a midline incision, liver was exposed and lifted with a moisturized cotton swab (soaked with $0.9 \% \mathrm{NaCl}$ solution). The bile duct was exposed by caudal movement of the gut, placing the 5-0 mersilk suture around the bile duct and securing it with two surgical knots, then, adding a second cranial ligation in the same manner. The abdominal organs were replaced back, and abdominal layers were closed with chromic and 6-0 mersilk sutures.

Sampling: 4 weeks after the operation, rats were anaesthetized with intraperitoneal injection of thiopental sodium (EIPICO, Egypt), in a dose of $40 \mathrm{mg} / \mathrm{kg} \mathrm{B}$.W. The abdominal aorta was then exposed and cannulated with a polyethylene catheter for blood sampling.

Blood samples were collected into plastic tubes and centrifuged at $3000 \mathrm{rpm}$ for 15 minutes. Then the separated plasma was pipetted in aliquots into clean tubes and stored at $-80^{\circ} \mathrm{C}$. Livers were immediately dissected out. A portion of the liver tissue (obtained from median lobe) was homogenized in ice-cooled phosphate buffer saline, using IKA-WERK, Ultra-Turrax, West Germany to obtain $10 \%$ homogenate. Aliquots of the liver homogenate were stored at $-80^{\circ} \mathrm{C}$ prior to biochemical analysis. 
Assessment of biochemical parameters: ALT, AST, ALP and direct bilirubin were quantitatively assessed according to Burtis A. et al., [16]. Colorimetric method was used to assess plasma level of total proteins and total antioxidant capacity according to Koracevic et a1., [17]. Malondialdehyde (MDA) level was measured in the liver tissue homogenate according to Yagi, K. [18] Kits of previous parameters were supplied by Bio Diagnostic Company (Cairo, Egypt). ELIZA technique was used to measure plasma level of tumor necrosis factor alpha (TNF-a) and level of transforming growth factor beta 1 (TGF- $j^{\prime} 1$ ) in liver tissue. ELIZA kits were purchased from Fine test-Wuhan, Hubei, China. All assays were performed according to the manufacturer's instruction.

Histopathological examination: A part of the median lobe of the liver was placed in 10\% formalin for 48 hours, stained with hematoxylin and eosin and then examined with a light microscope for pathological changes. The histopathological reports were performed blindly.

Statistical analysis: Data were presented as mean SEM. Statistical analysis of the data was carried out using one way analysis of variance (ANOVA). Statistical significance was acceptable to a level of $\mathrm{p}<0.05$. Data analysis was accomplished using the Statistical Package for Social Sciences (SPSS) software program (version 20).

\section{Results}

Both body weight and body mass index were insignificantly changed among all studied groups. On the other hand, liver weight and hepatosomatic index were both significantly increased in BDL group compared to control one. In O-BDL group, liver weight and hepatosomatic index were significantly increased compared to control group but wre insignificantly changed in respect to BDL group (Table 1).

In comparison to control group, plasma levels of ALT, AST, ALP and direct bilirubin significantly increased in the BDL rats and were non-significantly different in O-BDL rats. These parameters were significantly decreased in O-BDL rats compared to the BDL group. Total proteins level was not significantly different amongst all the studied groups (Table 2).

Plasma TAC significantly decreased and liver tissue MDA level significantly increased in in BDL rats compared to the control group. Upon onion supplementation TAC level was significantly in- creased and MDA level was significantly decreased in O-BDL rats compared to BDL group. On the other hand, the level of both TAC and MDA were not significantly changed in the $\mathrm{O}$-BDL group compared to the control group (Table 3).

The plasma level of TNF-a and level of liver TGF-(31 were both significantly increased in the $\mathrm{BDL}$ rats compared to control one. Onion supplementation resulted in a significant decrease in their levels compared to the BDL group, although their levels still remained significantly higher than the control group (Table 3).

Table (1): Anthropometric studies; body weight (BW), Length, body mass index (BMI), liver weight (Liver wt) and hepatosomatic index (HS index) in the different studied groups.

\begin{tabular}{|c|c|c|c|}
\hline & $\begin{array}{l}\text { Control } \\
\text { group } \\
\text { (c) }\end{array}$ & $\begin{array}{l}\text { Bile duct } \\
\text { ligation group } \\
\text { (BDL) }\end{array}$ & $\begin{array}{l}\text { Onion-supplemented } \\
\text { bile duct ligated } \\
\text { group (O-BDL) }\end{array}$ \\
\hline \multicolumn{4}{|l|}{$B W(g):$} \\
\hline Meant SEM & 186.55 .7 & $197.5 \pm 15.6$ & $168.9 \pm 8.8$ \\
\hline \multicolumn{4}{|l|}{ Length $(\mathrm{cm})$ : } \\
\hline Mean \pm SEM & $19.4 \pm 0.2$ & $19.1 \pm 0.4$ & $18.2 \pm 0.2^{\mathrm{a}, \mathrm{b}}$ \\
\hline \multicolumn{4}{|l|}{ Bum $\left(\mathrm{g} / \mathrm{cm}^{2}\right):$} \\
\hline Mean \pm SEM & $0.49 \pm 0.01$ & $0.53 \pm 0.02$ & $0.51 \pm 0.01$ \\
\hline \multicolumn{4}{|l|}{ Liver wt (g): } \\
\hline Mean \pm SEM & $5.8 \pm 0.2$ & $9.1 \pm 0.8 \mathrm{a}$ & $8.5 \pm 0.7 a$ \\
\hline \multicolumn{4}{|l|}{ HS index (gig): } \\
\hline Mean \pm SEM & $0.03 \pm 0.001$ & $0.05 \pm 0.003 a$ & $0.05 \pm 0.003 a$ \\
\hline
\end{tabular}

a: Significance by LSD atp $<0.05$ from the control group. $\mathrm{b}$ : Significance by LSD at $\mathrm{p}<0.05$ from the BDL group.

Table (2): Plasma level of alanine aminotransferase (ALT), aspartate aminotransferase (AST), alkaline phosphatase (ALP), total proteins and direct bilirubin in the different studied groups.

\begin{tabular}{lccc}
\hline & $\begin{array}{c}\text { Control } \\
\text { group } \\
(\mathrm{C})\end{array}$ & $\begin{array}{c}\text { Bile duct } \\
\text { ligation group } \\
\text { (BDL) }\end{array}$ & $\begin{array}{c}\text { Onion-supplemented } \\
\text { bile duct ligated } \\
\text { group (O-BDL) }\end{array}$ \\
\hline $\begin{array}{c}\text { ALT (UIL): } \\
\text { Mean } \pm \text { SEM }\end{array}$ & $25.94 \pm 1.940$ & $40.32 \pm 4.054 \mathrm{a}$ & $22.80 \pm 2.663 \mathrm{~b}$ \\
$\begin{array}{l}\text { AST (UlL): } \\
\text { Mean } \pm \text { SEM }\end{array}$ & $2.05 \pm 0.128$ & $103.60 \pm 0.349 \mathrm{a}$ & $2.34 \pm 0.151 \mathrm{~b}$ \\
$\begin{array}{l}\text { ALP (UIL): } \\
\text { Mean } \pm \text { SEM }\end{array}$ & $3.56+0.476$ & $7.42 \mathrm{i}-0.64 \mathrm{a}$ & $4.72 \pm 0.641 \mathrm{~b}$ \\
$\begin{array}{l}\text { Total protein } \\
\text { (g/L): }\end{array}$ & & & \\
Mean \pm SEM & $6.68+0.274$ & $6.27 \pm 0.364$ & $633+0.368$ \\
$\begin{array}{l}\text { Direct bilirubin } \\
\text { (mgldL): }\end{array}$ & & & \\
Meant SEM & $0.125 \pm 0.018$ & $0.954 \pm 0.414 \mathrm{a}$ & $0.178 \pm 0.050 \mathrm{~b}$ \\
\hline
\end{tabular}

a: Significance by LSD atp $<0.05$ from the control group. b: Significance by LSD at $p<0.05$ from the BDL group. 


\section{Results of histopathological examination:}

Examination of H\&E-stained liver sections of control rats showed the general appearance of classic hepatic lobules formed of central vein and peripheral portal tracts (Fig. 1a). Cords of hepatocytes were seen radiating from the central vein in branching and anastomosing pattern. Hepatocytes appeared polygonal in shape with acidophilic cytoplasm and central rounded vesicular nuclei, and some hepatocytes were seen binucleated. Blood sinusoids were slit like and were lined with flat endothelial cells (Fig. lb). Portal tracts contained bile duct, branches from hepatic artery, and portal vein.

Examination of $\mathrm{H} \&$ E-stained liver sections from BDL group showed loss of normal hepatic architecture. Most portal tract areas were seen expanded. Areas of mononuclear cellular infiltration were fre- quently seen between hepatocytes (Fig. 2a). Most hepatocytes were seen with deep acidophilic cytoplasm and dense pyknotic nuclei, others were seen with small shrunken deeply stained nuclei. Some hepatic sinusoids were seen dilated (Fig. 2b). Dilated congested portal vein branches and proliferated bile ducts were frequently seen in most portal tracts (Fig. $2 \mathrm{c} \& \mathrm{~d})$.

Examination of H\&E-stained liver sections from onion-supplemented bile duct ligated group (O-BDL) showed few classic hepatic lobules with areas of mononuclear cellular infiltration (Fig. 3a). Few portal tracts were seen expanded with areas of mononuclear cellular infiltration and proliferation of bile ducts. Most hepatocytes were seen with acidophilic cytoplasm and central vesicular nuclei, like control group (Fig. 3b).

Table (3): Plasma level of total antioxidant capacity (TAC), liver tissue level of malondialdehyde (MDA), plasma level of tumor necrosis factor a (TNF-a) and liver tissue level of transforming growth factor (31 (TGF-(31) in the different studied groups.

\begin{tabular}{|c|c|c|c|}
\hline & $\begin{array}{l}\text { Control } \\
\text { group } \\
\text { (C) }\end{array}$ & $\begin{array}{l}\text { Bile duct } \\
\text { ligation group } \\
\text { (BDL) }\end{array}$ & $\begin{array}{l}\text { Onion-supplemented } \\
\text { bile duct ligated } \\
\text { group (O-BDL) }\end{array}$ \\
\hline \multicolumn{4}{|l|}{$\operatorname{TAC}(m, n o l / L):$} \\
\hline Mean 1 SEM & 4.6510 .681 & $0.3310 .041 \mathrm{a}$ & $3.78 \mathrm{t} 0.139 \mathrm{~b}$ \\
\hline \multicolumn{4}{|l|}{ MDA (umol/g): } \\
\hline Mean \pm SEM & $132.60 \pm 14.663$ & $204.56 \pm 33.500 \mathrm{a}$ & $102.62 \pm 7.149 b$ \\
\hline \multicolumn{4}{|l|}{$T N F-a(p g / n d):$} \\
\hline Mean \pm SEM & $20.85 \pm 2.670$ & 225 45ŕ42.698a & $115.91 \pm 17.929 \mathrm{a}$ 'b \\
\hline \multicolumn{4}{|l|}{$T c F-11$ (pgig): } \\
\hline Mean \pm SEM & $167.10 \pm 10.133$ & $885.6359 .315 a$ & 432.2020.650a'b \\
\hline
\end{tabular}

a: Significance by LSD atp $<0.05$ from the control group.

b: Significance by LSD at $\mathrm{p}<0.05$ from the BDL group.

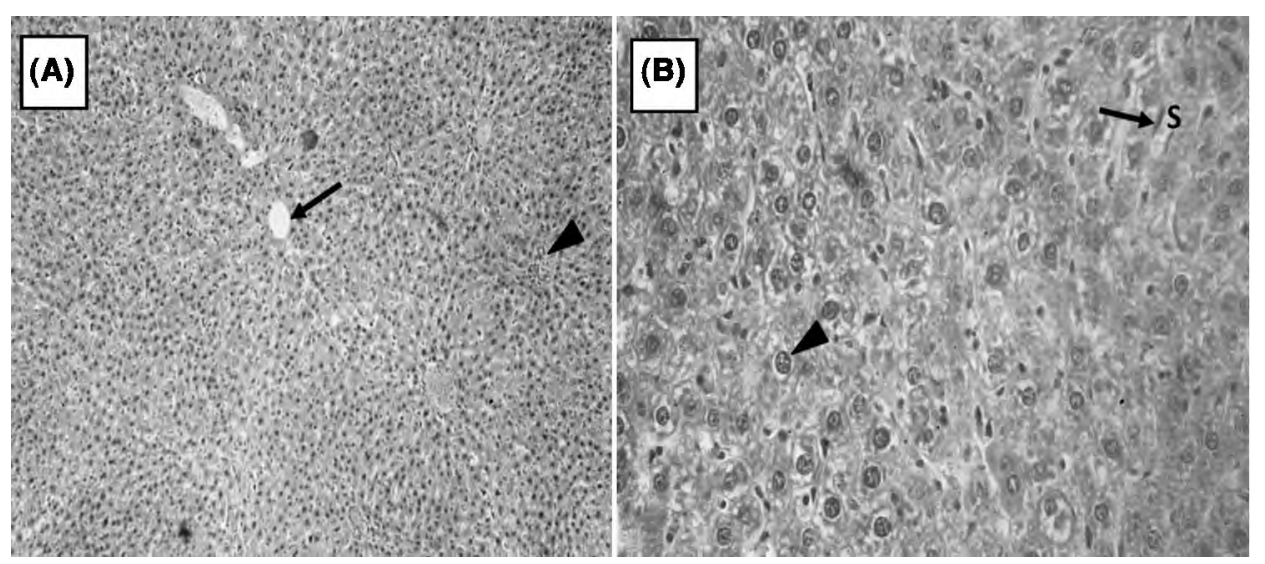

Fig. (1A,B): (1A): A photomicrograph of liver of the control rats showing the general appearance of classic hepatic lobules formed of central vein (f) and peripheral portal tracts (A), (H \& E x100). (1B): Hepatocytes are polygonal in shape with acidophilic cytoplasm containing basophilic granules and central rounded vesicular nuclei (A). Some hepatocytes are seen binucleated. Blood sinusoids (S) are slit like spaces and are lined with flat endothelial cells (f), (H\& E x400). 

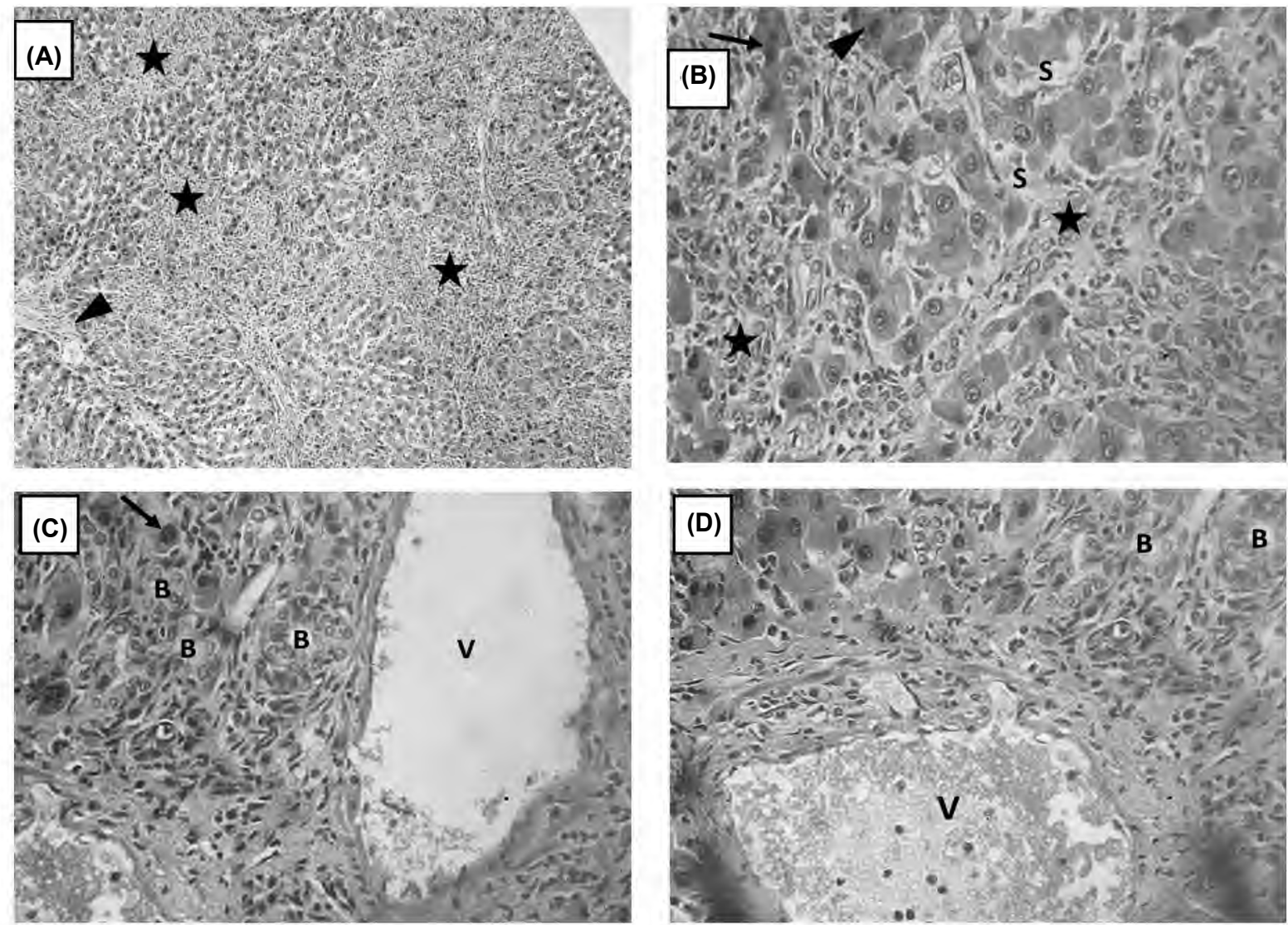

Fig. (2A,B,C,D): (2A): A photomicrograph of liver of the bile duct ligated group (BDL) showing loss of normal hepatic architecture and expanded portal tract area $(\mathbf{A})$. Areas of mononuclear cellular infiltration $\left(^{*}\right)$ are seen between hepatocytes, (H \& E x 100). (2b): Showing dilated hepatic sinusoids (S) and mononuclear cellular infiltration (*) between hepatocytes. Some hepatocytes are seen with deep acidophilic cytoplasm and dense pyknotic nuclei $(\mathbf{\Lambda})$, others are seen with small shrunken deeply stained nuclei $(\uparrow)$, (H \& E x400). (2C): Expanded portal tract area with dilated portal vein branch (V) and proliferated bile ducts (B). Hepatocytes with deeply stained nuclei $(A)$ are seen, (H \& E x 400). (2D): Expanded portal tract with dilated congested portal vein branch (V). Proliferation of bile ducts were seen (B), (H \& E x400).
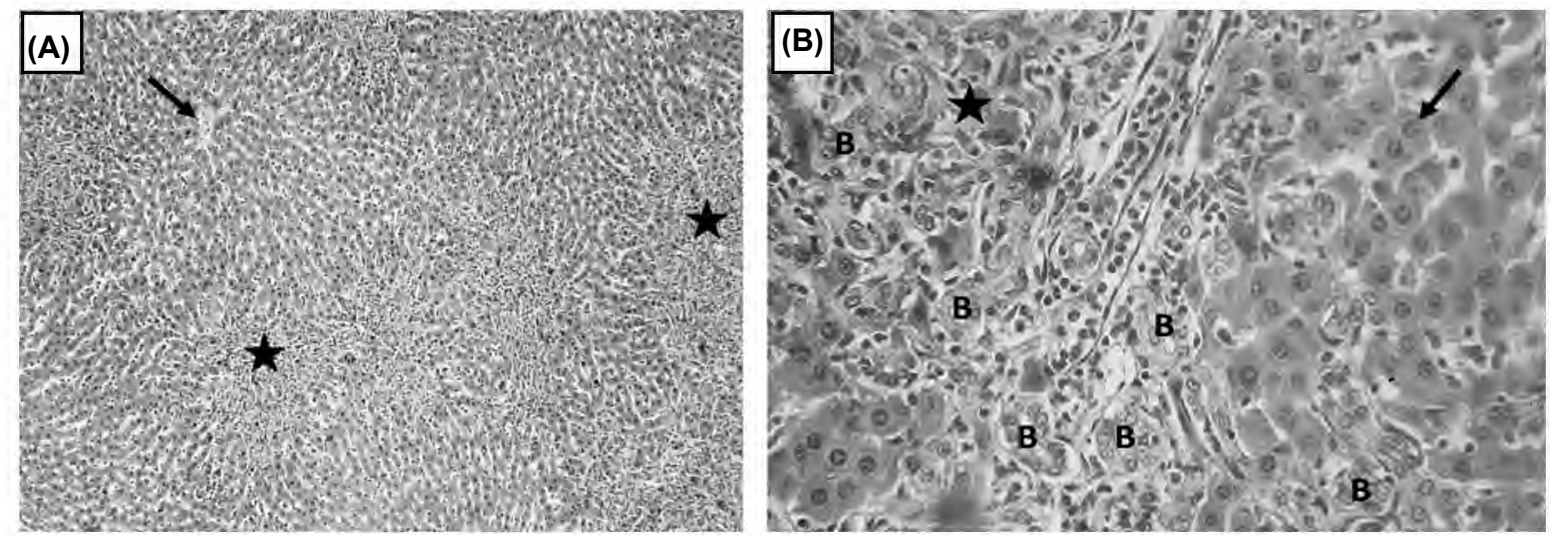

Fig. (3A,B): A photomicrograph of liver of the onion-supplemented bile duct ligation group (O-BDL). (3A): Showing central vein $(\uparrow)$ in a classic hepatic lobule. Areas of mononuclear cellular infiltration $\left(^{*}\right)$ are seen, $(H$ \& $E$ x100). (3B): Showing expanded portal tract with mononuclear cellular infiltration $\left(^{*}\right)$ and proliferation of bile ducts $(B)$. Hepatocytes with acidophilic cytoplasm and central vesicular nuclei are seen ( $\uparrow),($ H \& E x400).

\section{Discussion}

The results of the present study clearly demonstrate that BDL model of experimental cholestasis induces hepatic oxidative stress and hepatic inflam- mation, which ultimately distort the liver architectural structure and deteriorate hepatic functions. Onion supplementation decreased the oxidative stress, and partially decreased the inflammatory processes that disrupt hepatic structure and functions. 
Ligation of the common bile duct in rodents is an experimental model of cholestasis that has been carried out in research for many years [19]. The results of increased hepatic enzymes ALT, AST and ALP, and direct bilirubin detected in the BDL group of this study clearly demonstrate the hazardous effects of BDL and the subsequent cholestasis on liver functions. These results are in agreement with previous literature indicating that BDL and the subsequent bile acid regurgitation to the liver induce toxic hepatic injury, hepatocellular necrosis, epithelial proliferation of bile ducts cells, and subsequently solubilize membrane phospholipids leading to the release of intracellular enzymes [2022]

In the present study the results of BDL-induced liver injury could be explained by the accumulation of bile acids in the bile ducts and in the liver tissue, with the production of reactive oxygen species (ROS) in the liver of the BDL rats. This explanation is confirmed by the significant decrease in plasma TAC and the significant increase in liver tissue MDA that reflects the depletion of the antioxidant defenses and excessive production of reactive oxygen species. This state of imbalance between oxidative stress and antioxidant defenses lead to increased membrane lipid peroxidation and hepatic cell damage, which was detected by the increase in plasma levels of liver enzymes in the BDL group of the present study.

These findings illustrate the primary role of oxidative stress in the pathophysiology of cholestatic liver injury, and are in accordance to results reported by other recent researches in mice and rats [23-25].

Further, the cholestatic- induced oxidative stress in the BDL rats of the present study is a major underlying factor in the production of inflammatory liver injury. The inflammatory state is confirmed by the significant increase in plasma levels of TNF$\alpha$ in the BDL group compared to the control group. Parenchymal hepatic cells are the primary cells involved in oxidative hepatic injury [26]. The mitochondria, microsomes and peroxisomes in parenchymal cells can produce ROS. Hepatic stellate cells, Kupffer cells, and endothelial cells of bile duct are very sensitive to oxidative stress-related molecules. Kupffer cells exposed to oxidative insults produce a variety of inflammatory cytokines like TNF- $\alpha$, which increase hepatocellular inflammation and apoptosis. BDL-induced cholestasis in the present study was associated with increased levels of proinflammatory cytokines. Thus, oxidative injury and inflammatory necrosis are the major mechanisms involved in cholestatic liver injury. [27].

Further, significant increase in liver tissue level of TGF- $\beta 1$ detected in the BDL rats, reflects the increased liability to hepatic fibrosis secondary to BDL. Although the histological picture of the livers of BDL rats did not show excessive collagen deposition or fibrotic changes in the hepatic tissue though, the increased liver TGF- $\beta 1$ in the BDL group indicate the profibrotic state of BDL rat's livers.

The biliary obstruction by BDL causes hepatocellular necrosis, proliferation of bile ductular epithelial cells and activation of stellate cells [28] and subsequent release of cytokines and growth factors which stimulate the extracellular matrix deposition leading to hepatic fibrosis [29].

TGF- $\beta 1$ is a fibrogenic mediator play a critical role in activation, trans-differentiation of hepatic stellate cells (HSCs) and extracellular matrix deposition producing liver fibrosis $[\mathbf{2 3 , 3 1}$. Several mechanisms are responsible for the increased liver tissue levels of TGF- $\beta 1$ in the BDL group. According to Seki and Schwabe [32]

Inflammation, demonstrated by the increased TNF- $\alpha$, is commonly associated with hepatic fibrogenesis during chronic liver diseases. Moreover, El-Swefy et al., [33] reported that oxidative stress and inflammation are major contributing factors in hepatic fibrogenesis during cholestasis.

Onion supplementation to BDL rats was associated with a significant decrease in plasma levels of liver enzymes; ALT, AST and ALP, and in level of direct bilirubin. These results are in accordance to previous findings regarding the protective effects of onion and its extracts on hepatic toxicity induced by different agents [34]. The bulbs of onion and its extract were studied for their hepatoprotective effects against carbon tetrachloride, ethyl acetate and paracetamol induced liver toxicity in Wistar rats. Paracetamol, ethyl acetate and carbon tetrachloride in high doses induced significantly elevated serum levels of liver enzymes and bilirubin, with alterations in the structure and function of liver cells. In their study they have observed that the elevated levels of biochemical parameters were significantly got reduced by the treatment with onion and its extract interfere with cytochrome P450 monooxygenase, thus reducing the hepatotoxic free radicals. In the present study, cholestatic damage to the liver resulted in increased plasma levels of these enzymes. Onion supplementation showed the ability to ameliorate cholestatic liver 
damage and maintain the integrity of hepatocytes. Similar findings were detected by Ige et al., [3я and were attributed to the effect of onion in ROS scavenging.

Further confirmation on the ROS scavenging effects of onion in the present study were apparent in the results of the significant decrease in liver tissue MDA and the significant increase in the plasma TAC activity in the onion supplemented $\mathrm{BDL}$ group compared to the BDL group. These antioxidant effects of onion were documented in many previous literature $[35,36]$.

Moreover, onion supplemented group of the present study showed a significant decrease in plasma level of TNF- $0 \tau$ and in liver tissue level of TGF-rз compared to the BDL group, demonstrating the anti-inflammatory effects of onion and its constituents. These findings are in agreement with study demonstrating a potential anti-inflammatory and immunomodulatory effects of onion by decreasing TNF- $0 \tau$ and TGF- $Г 31$ [37]

Moreover, in the study of Anbu et al., [38], on the beneficial effects of morin, which is a bioflavonoid found in different herbs and fruits including onion, it was concluded that flavonoids can alleviate ethanol-induced liver fibrosis, as evidenced by the decrease in hepatic enzyme levels and in TGF- $г 3$.

Histopathology of liver of onion supplemented rats also showed hepatoprotective effect, with regain of near normal architecture. Similar previous data demonstrated the hepatoprotective effect of onion on liver morphology [3я

Several literature clarified the beneficial effects of flavonoid constituents of onion on hepatic functions. Kim et al., [39] reported that $0.8 \mathrm{~g} / \mathrm{kg}$ quercetin for 8 weeks led to decrease in liver injury, liver enzymes and oxidative stress in rats fed a high fat diet. Charytoniuk et al., [40] found that $50 \mathrm{mg} / \mathrm{kg}$ quercetin for 2 weeks or 4 weeks decreased hepatic steatosis, TNF- $0 \tau$ and TGF-гз 1 in mice with nonalcoholic fatty liver disease.

We herein demonstrated that BDL-induced hepatic oxidative stress, inflammation and injury. This was characterized by marked biochemical, morphological and pathophysiological abnormalities induced by obstructed hepatic biliary tree, and subsequently retention of biliary constituents. The deleterious effect of BDL on liver function is emphasized by significant rise in plasma AST, ALT, ALP, direct bilirubin, TNF- $0 \tau$, and hepatic tissue levels of MDA and TGF- Г3, with concomitant decrease in plasma TAC in BDL group of rats as compared with the control group. In addition, the liver tissue of BDL rats revealed congested vessels, cellular infiltration and dilated bile duct system on histopathological examination.

Moreover, results of the present study revealed the presence of considerable amounts of antioxidants and anti-inflammatory effects of onion. The presence of such effects provides an evidence for the hepatoprotective effect and antioxidant capacity of onion, as revealed by significant reduction of hepatic enzymes, direct bilirubin, TNF- $0 \tau$, and hepatic tissue levels of MDA and TGF- $\mathrm{I}_{3}$, with concomitant elevation in plasma TAC in the onion supplemented group as compared with BDL group.

\section{Conclusion:}

In Conclusion, BDL induces hepatic structural alterations and functional disturbances. Onion supplementation inhibits inflammation and oxidative insults that associate BDL, and subsequently protects against BDL-induced liver injury.

\section{References}

1- CROCENZI F.A., ZUCCHETTI A.E., BOAGLIO A.C., BAROSSO I.R., SANCHEZ POZZI E.J., MOTTINO A.D., et al.: Localization status of hepatocellular transporters in cholestasis. Front Biosci., 17: 1201-18, 2012.

2- GHONEM N.S., ASSIS D.N. and BOYER J.L.: Fibrates and cholestasis: A review. Hepatology, 62 (2): 635-43, 2015.

3- JANG J.H., RICKENBACHER A., HUMAR B., WEBER A. and RAPTIS D.A.: Serotonin protects mouse liver from cholestatic injury by decreasing bile salt pool after bile duct ligation. Hepatology, 56: 209-18, 2012.

4- ALLEN K., JAESCHKE H. and COPPLE B.L.: Bile Acids Induce Inflammatory Genes in Hepatocytes: A Novel Mechanism of Inflammation during Obstructive Cholestasis. The American Journal of Pathology, 178 (1): 175-86, 2011

5- COPPLE B.L., JAESCHKE H. and KLAASSEN C.D.: Oxidative stress and the pathogenesis of cholestasis. Semin Liver Dis. 30: 195-204, 2010.

6- ALAM M.M., MEERZA D. and NASEEM I.: Protective effect of quercetin on hyperglycemia, oxidative stress and DNA damage in alloxan induced type 2 diabetic mice Life Sciences Journal, 109 (1): 8-14, 2014.

7- LIAO YR and LIN JY.: Quercetin intraperitoneal administration ameliorates lipopolysaccharide-induced systemic inflammation in mice. Life. Sci., 137: 89-97, 2015.

8- BENKEBLIA N.: Antimicrobial activity of essential oil extracts of various onions (Allium cepa) and garlic (Allium sativum) Lebensm.Wiss. u.Technol., (37): 263-8, 2004.

9- GRIFFITHS G., TRUEMAN L., CROWTHER T., THOMAS B. and SMITH B.: Onions-a global benefit to health. Phytother. Res., 16: 603-15, 2002. 
10- SLIMESTAD R., FOSSEN T. and VAGEN I.M.: Onions: A source of unique dietary flavonoids. J. Agric. Food. Chem., 55 (25): 10067-80, 2007.

11-LEE C.C., SHEN S.R., LAI Y.J. and WU S.C.: Rutin and quercetin, bioactive compounds from tartary buckwheat, prevent liver inflammatory injury. Food Funct., 4: 794802, 2013.

12- SUN X., YAMASAKI M., KATSUBE T. and SHIWAKU K.: Effects of quercetin derivatives from mulberry leaves: improved gene expression related hepatic lipid and glucose metabolism in short-term high-fat fed mice. Nutr. Res. Pract., 9: 137-43, 2015.

13- Guide for the care and use of laboratory animals. Eighth Edition. The national academic press. Washington, DC. 20001.

14- VINOTH KUMAR P., AMALA PRICY A., SUDHEER KUMAR Ch., VIMOL V. and VEERA THAMARAI SELVI V.: Hypolipidemic effect of allium cepa. Linn (onion) in lead acetate intoxicated male albino rats. Der Pharmacia Sinica, 1 (3): 64-8, 2010.

15- TAG C.G., SAUER-LEHNEN S., WEISKIRCHEN S., BORKHAM-KAMPHORST E., TOLBA R.H., TACKE F., et al.: Bile duct ligation in mice: Induction of inflammatory liver injury and fibrosis by obstructive cholestasis. Journal of visualized experiments: JoVE, 96: 52438, 2015.

16- BURTIS A., et al.: Tietz Textbook of Clinical Chemistry, 3rd ed AACC, 1999.

17- KORACEVIC D., KORACEVIC G., DJORDJEVIC V., ANDREJEVIC S. and COSIC V.: Method for the measurement of antioxidant activity in human fluids. J. Clin. Pathol., 54 (5): 356-61, 2001.

18- Yagi K.: (17) Free Radicals and Antioxidant Protocols. 108: 101-106, 1998.

19- SHEEN J.M., HUANG L.T., HSIEH C.S., CHEN C.C., WANG J.Y. and TAIN Y.L.: Bile duct ligation in developing rats: temporal progression of liver, kidney, and brain damage. Journal of Pediatric Surgery, 45 (8): 16508, 2010 .

20- ALI S.I., SAID M.M., HASSAN M. and KHEDRE E.: Prophylactic and curative effects of purslane on bile duct ligation-induced hepatic fibrosis in albino rats. Ann. Hepatol., 10 (3): 340-6, 2011.

21- ALE-EBRAHIM M., EIDI A., MORTAZAVI P., TAVANGAR S.M. and TEHRANI D.M.: Hepatoprotective and antifibrotic effects of sodium molybdate in a rat model of bile duct ligation. Journal of Trace Elements in Medicine and Biology, 29: 242-8, 2015.

22- CHEN Z., ZHU Y., ZHAO Y., MA X., NIU M, WANG J., et al.: Serum metabolomic profiling in a rat model reveals protective function of paeoniflorin against ANIT induced cholestasis. Phytotherapy Research, 30 (4): 65462, 2016.

23- WEERACHAYAPHORN J., LUO Y., MENNONE A., SOROKA C.J., HARRY K. and BOYER J.L.: Deleterious effect of oltipraz on extrahepatic cholestasis in bile ductligated mice. Journal of Hepatology, 60 (1): 160-6, 2014.

24- CAO Y.W., JIANG Y., ZHANG D.Y., WANG M., CHEN W.S., SU H., et al.: Protective effects of Penthorum chinense Pursh against chronic ethanol-induced liver injury in mice. Journal of Ethnopharmacology, 161: 928, 2015.

25- FAHMY S.R.: Anti-fibrotic effect of Holothuria arenicola extract against bile duct ligation in rats. BMC Complementary and Alternative Medicine, 15 (1): 14, 2015.

26- WOOLBRIGHT B.L., ANTOINE D.J., JENKINS R.E., BAJT M.L., PARK B.K. and JAESCHKE H.: Plasma biomarkers of liver injury and inflammation demonstrate a lack of apoptosis during obstructive cholestasis in mice. Toxicology and Applied Pharmacology., 273 (3): 524-31, 2013.

27- CICHOZ-LACH H. and MICHALAK A.: Oxidative stress as a crucial factor in liver diseases. World Journal of Gastroenterology, 20 (25): 8082, 2014.

28- HONG J.Y., SATO E.F., HIRAMOTO K., NISHIKAWA M. and INOUE M.: Mechanism of liver injury during obstructive jaundice: Role of nitric oxide, splenic cytokines, and intestinal flora. J. Clin. Biochem. Nutr., 40: 184-93, 2007.

29- LÓPEZ-SÁNCHEZ L.M., CORRALES F.J., BARCOS M., ESPEJO I., JUAN R. MUÒOZ-CASTAÒEDA and RODRÍGUEZ-ARIZA A.: Inhibition of nitric oxide synthesis during induced cholestasis ameliorates hepatocellular injury by facilitating S-nitrosothiol homeostasis. Lab. Invest., 90: 116-27, 2010.

30- LEASK A. and ABRAHAM D.J.: TGF- $\beta$ signaling and the fibrotic response. FASEB J., 18: 816-27, 2004.

31- VERRECCHIA F. and MAUVIEL A.: Transforming growth factor-beta and fibrosis. World J. Gastroenterol., 13: 305662, 2007.

32- SEKI E. and SCHWABE R.F.: Hepatic inflammation and fibrosis: functional links and key pathways. Hepatology, 61 (3): 1066-79, 2015.

33- EL-SWEFY S. and HASSANEN S.I.: Improvement of hepatic fibrosis by leukotriene inhibition in cholestatic rats. Ann. Hepatol., 8: 41-9, 2009.

34- RAWAT M.S. and DUTT K.R.: Comparison of ethyl acetate extracts of Allium cepa bulbs, Luffa acutangula fruits, Nyctanthes arbostristis leaves, Swertia chirata twigs and Woodfordia floribunda leaves with Silymarin for hepatoprotective activity. Plant Archives, 7 (1): 183-6, 2007.

35- IGE S.F., AKHIGBE R.E., EDEOGHO O., AJAO F.O., OWOLABI O.Q., OYEKUNLE O.S. and AJAYI A.F.: Hepatoprotective activities of allium cepa in cadmiumtreated rats. International Journal of Pharmacy and Pharmaceutical. Sciences, 3 (5): 60-3, 2011.

36- EMAMAT H., FOROUGHI F., EINI-ZINAB H., TAGHIZADEH M., RISMANCHI M. and HEKMATDOOST A.: The effects of onion consumption on treatment of metabolic, histologic, and inflammatory features of nonalcoholic fatty liver disease. Journal of Diabetes \& Metabolic Disorders. Jul., 22 (15): 25, 2016.

37- ELBERRY A.A., MUFTI S., AL-MAGHRABI J., ABDEL SATTAR E., GHAREIB S.A., MOSLI H.A., et al.: Immunomodulatory effect of red onion (Allium cepa Linn) scale extract on experimentally induced atypical prostatic 
hyperplasia in Wistar rats. Mediators of Inflammation, $13,2014$.

38- ANBU P., KANG C.H., SHIN Y.J. and SO J.S.: Formations of calcium carbonate minerals by bacteria and its multiple applications. Springer Plus, 5 (1): 250, 2016.

39- KIM T.W., LEE D.R., CHOI B.K., KANG H.K., JUNG J.Y., LIM S.W., et al.: Hepatoprotective effects of polymethoxyflavones against acute and chronic carbon tetrachloride intoxication. Food and Chemical Toxicology, 91: 91-9, 2016.

40- CHARYTONIUK T., DRYGALSKI K., KONSTANTYNOWICZ-NOWICKA K., BERK K. and CHABOWSKI A: Alternative treatment methods attenuate the development of NAFLD: A review of resveratrol molecular mechanisms and clinical trials. Nutrition, 34: 108-17, 2017.

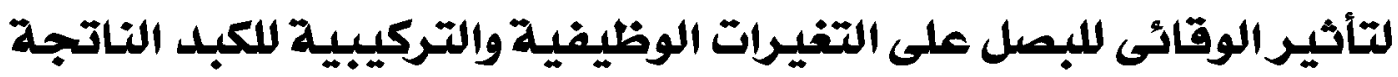 عن إحتباس العصارة الصفرات الوفيلة الصئة}

خلفية البحث: الركود الصفراوى هو عرقلة أو إنخفاض فى تدفق العصارة الصفراوية والتى ينتج عنها تراكم مكونات العصارة الصفراوية

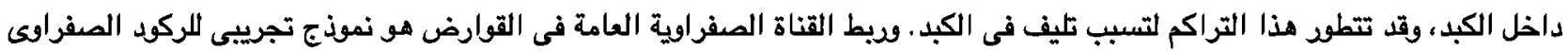

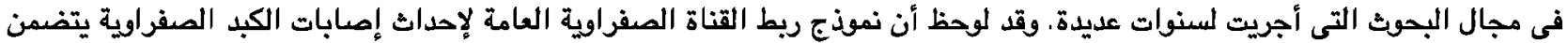



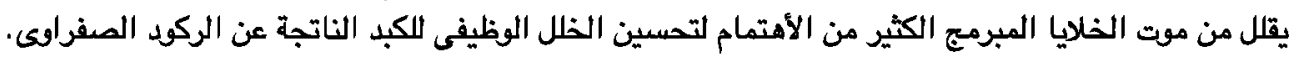

الهدف من العهل: تهدف هذه الدراسة إلى تقييم التأثيرات الوقائية البصل على التغيرات التركييية والوظيفية الكبدية والتى يسبيها ربط

القناة الصفراوية العامة فى الفئران.

المواد والأساليب: أجريت هذه الدراسة على ثلاثين فئراً من الإناث، تم توزيعها بشكل عشوائى وبصورة متساوية على ثلاث مجموعات: 1- المجموعة الأولى: المجموعة الضابطة.

r- المجموعة الثانية: مجموعة ربط القناة الصفراوية العامة ويدون تقديم أى معالجة.

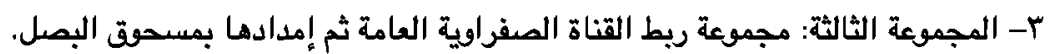

وقد تلقت المجموعة الأولى والثانية الماء المقطر (المذيب لمسحوق الصـل) يومياً عن طريق الفم لمدة أربع أسابيع. أما المجموعة الثالثة فقد إمدادها بمسحق البصل بجرعة . .0 كجم/كجم من هنت الفئران يومياً عن طريق الفم لمدة أربع أسابيع.

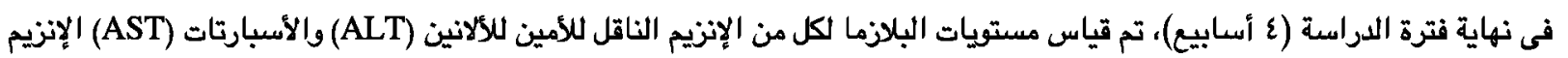

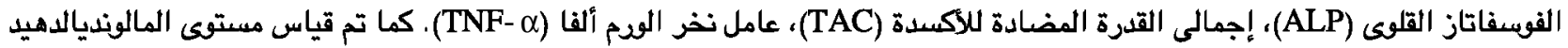
(MDA) وعامل النمو التحولى بيتا (TGF- في أنسجة الكبد جميع المجموعات. بالإضافة الى فحص هستولوجى لعينات من أنسجة الكبد المجموعات الثالثة.

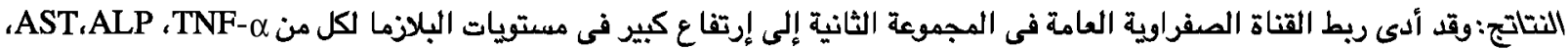



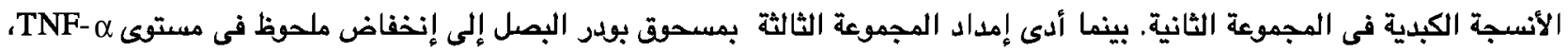
مستوى ALT،AST،ALP

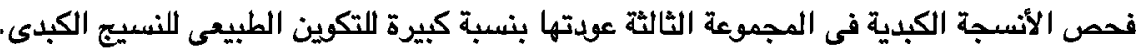

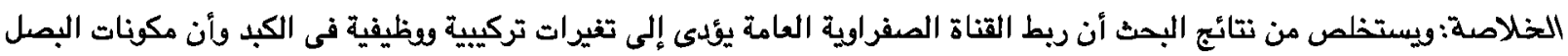

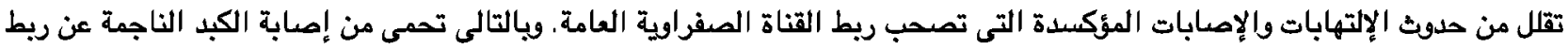

